\title{
Bioavailability and Risk Profile of Toxic Metals in Size Segregated Particulate Matter at different Traffic Junctions of Northern India
}

\section{Rahul Tiwari}

GLA University

\author{
Akshay Botle \\ Institute of Science
}

Prabal Singh

GLA University

Ajay Taneja ( $\square$ ataneja5@hotmail.com )

Institute of Basic Science, department of chemistry, Dr. B. R. Ambedkar University, Agra

\section{Research Article}

Keywords: Size segregated PM, Metals, PCA, Bioavailability, Health Risk Assessment

Posted Date: August 20th, 2021

DOI: https://doi.org/10.21203/rs.3.rs-819646/v1

License: (a) (i) This work is licensed under a Creative Commons Attribution 4.0 International License. Read Full License 


\section{Abstract}

Air quality at two traffic junctions representing GLA (highway pollution) and Iradatnagar (rural pollution) was evaluated In India. Present study aimed to determine the concentration of size-segregated PM with characterization of metals at different traffic junctions (Agra and Mathura). $\mathrm{PM}_{2.5-1.0}$ and $\mathrm{PM}_{1.0-0.5}$ was measured with the help of Cascade SioutasImpactor during the study period December to January 2018. The size fraction of $\mathrm{PM}_{2.5-1.0}$ was found higher at GLA $\left(350.92 \mu \mathrm{g} / \mathrm{m}^{3}\right)$ followed by Iradatnagar site $\left(329.12 \mu \mathrm{g} / \mathrm{m}^{3}\right)$ whereas average value of size fraction of $\mathrm{PM}_{1.0-0.5}$ was found higher at Iradatnagar site $\left(361.01 \mu \mathrm{g} / \mathrm{m}^{3}\right)$ in comparison with GLA $\left(313.47 \mu \mathrm{g} / \mathrm{m}^{3}\right)$ respectively. The average $\mathrm{PM}_{2.5}$ concentration in all the sampling sites was found 7-8 higher times than National Ambient Air Quality Standards $\left(60 \mu \mathrm{g} / \mathrm{m}^{3}\right)$ (NAAQS, India). Twelve Metals (Al, Ba, $\mathrm{Ca}, \mathrm{Cd}, \mathrm{Cr}, \mathrm{Cu}, \mathrm{Fe}, \mathrm{Mg}, \mathrm{Mn}, \mathrm{Ni}, \mathrm{Pband} \mathrm{Zn}$ ) subsequently determined by ICP-OES. Al, $\mathrm{Ba}, \mathrm{Ca}$, and $\mathrm{Mg}$, were found higher comparison to other metals. Metals source identification was done by PCA (Principal Component Analysis). The average value of HQs was found higher for $\mathrm{PM}_{1.0-0.5}$ size fraction. $\mathrm{HQ}$ values were recorded higher for GLA sampling site it was 7.95 for $\mathrm{PM}_{2.5-1.0}$ and 9.50 for $\mathrm{PM}_{1.0-0.5}$ fraction. Overall, the observed $\mathrm{HQ}$ s values far exceeded the acceptable level. The trend of average value of carcinogenic risk factor was found higher than prescribed limit $\left(1 * 10^{-}\right.$ ${ }^{6}$ ) for an adult and child respectively.

\section{Introduction}

Urbanization and industrialization growths are deteriorating the air quality. Air pollution is as vindicated as one of the lung causing cancer. The main source of air pollution is vehicular emissions, solid waste burning, coal combustion and soil dust. Heavy traffic through-out in modern societies increasing air pollution and declining the air quality. vehicles contributes about $70 \%$ of $\mathrm{CO}, 50 \%$ of $\mathrm{HC}, 30-40 \%$ of $\mathrm{NOx}$ and it has been found that vehicular emission acts as major contributing sources (62-85\%) prior over crustal source (10-35\%). (Pant et al. 2015; Villalobos et al. 2015). Particulate emission from on road vehicles contains a wide range of particle size from ultrafine $\left(<P M_{2.5}\right)$ to coarse range $\left(>P M_{10}\right)$. Vehicle emissions have been receiving increasing attention, and epidemiological studies show elevated risk to commuter and individuals living near roadways (Brugge et al. 2007; Singh et al. 2014). Vehicular emissions are not homogeneous it has a complete range of technological mixture that could be defined in terms of fuels (Gasoline diesel, Petrol, CNG) or engine used (2 stroke or 4 stroke). Particles emission from transport includes contribution from exhaust emission (fuel \& lubrication), emission from anthropogenic process (Tyre wear and brake lining emission) are responsible for secondary PM (Thorpe \& Harrison 2008). Globally, urban environment is contributing $25 \%$ of air pollution by $\mathrm{PM}_{2.5}, 15 \%$ by industrial activities, $20 \%$ from burning of domestic fuel, $22 \%$ undetermined source of human origin and $18 \%$ by natural dust and soils (Karagulian et al. 2015). Air pollution started in India with the development of transport system in 20th century and mass use of petrol and diesel (Srivastava\&Sarkar 2017). India is one of the fastest growing passenger car markets in the world; it is the second largest two wheeler maker and the fifth largest commercial vehicle manufacturer. In India, the industry produced a total of 
29,075,605 vehicles in March-April 2018, including passenger vehicles, commercial vehicles, three wheelers and two wheelers, statistics showed that vehicle growth increased by $14.78 \%$ over the years. The overall Commercial Vehicles segment grew by 19.94\%, Medium \& Heavy Commercial Vehicles grew by $12.48 \%$ and Light commercial vehicles grew by $25.42 \%$, three wheelers grew by $24.19 \%$. Within the three wheelers, passenger carrier \& goods carrier sales registered a growth of $28.65 \%$ and $7.83 \%$ respectively in April-March 2018.(http://www.motorindiaonline.in/commercial-vehicles/indian-cv-industryin-full-throttle/).Percentage emissions of $\mathrm{PM}_{2.5}$ from vehicles (old than 10 years) contribution reported as 2Wheelrs (30\%), 3Wheelers (42\%), 4Wheelers (58\%), buses (26\%), Light Duty vehicles (39\%) and high duty vehicles (46\%). The major twenty-nine cities of India account for $30-40 \%$ of the national on-road total emissions. (Guttikunda\& Mohan 2014). Current trends indicate that the vehicle movement on the road is one of the major contributors to urban air quality problems in India. Characterization of $\mathrm{PM}_{2.5}$ and its sources has been investigated in many studies (Yu et al. 2013; Tiwari et al. 2020).Adverse health effects are mainly associated with particle chemical composition with heavy toxic metals (Singh et al. 2017; Hildemann et al. 1991). Exposure to PM is the world's largest environmental health risk (Wallner et al. 2014) causing an estimated seven million deaths each year, equivalent to one in eight deaths across the globe (WHO, 2016). Numerous epidemiological studies have proposed a statistical association between health effect and ambient fine particle concentrations (Schwartz et al. 1996; Pope. 2002). $\mathrm{PM}_{2.5-1.0}$ and $\mathrm{PM}_{1.0-0.5}$ can penetrate deep into the alveolar region and thus should be specifically focused from an epidemiological viewpoint (Obersdoster, 2001). Numerous cardiovascular and respiratory illness studies have revealed the effects of fine aerosol on cardiopulmonary functions (Delfino et al. 2008; Kloog2016). In India research across the country regarding PM pollutant concentration were found to be well above the permissible limit. Information of pollutant on size segregated $P M\left(P_{2-5-1.0}\right.$ and $\left.\mathrm{PM}_{1.0-0.5}\right)$ is still sparse. The present study is aimed to provide information on the concentration level of size segregated PM at two different traffic junctions GLA University, Mathura (NH-19) and Iradatnagar (Rural traffic site) of Agra. The key objectives of this study are (1) To examine the concentration of metal constituent and size distribution of PM in different size fraction (2) To assess the bioavailability of metals (3) To assess the health risk assessment in terms of carcinogenic (Excess cancer risk) and non-carcinogenic (Hazard's quotient) through inhalation pathway. The results of this study could help the health officials/ environmentalists/ scientists and policy makers to gain insight about the toxicity of metal bound particles with a better understanding to control them.

\section{Methods And Methodology 2.1. Sampling Site}

Sampling was carried out at traffic site on National Highway-2 which has been renumbered as $\mathrm{NH}-19$ (Agra-Delhi National Highway) at GLA University Mathura, to explore the trends of concentration of pollutants on highway, 2nd site was rural traffic junction (Iradatnagar) in Agra district. The climate of Agra is a semi-arid. During summer, the day time temperature hovers around $46-48^{\circ} \mathrm{C}$. The city geography mild winters, hot summers and a monsoon season. Winters are bit chilly; temperature 
sometimes goes as low as 2 or $3^{\circ} \mathrm{C}$ but usually soars in the range of 6 to $8^{\circ} \mathrm{C}$. Sampling site GLA University, Mathura $\left(27.28^{\circ} \mathrm{N} 77.41^{\circ} \mathrm{E}\right)$ is situated on National Highway-2, which is busiest highway of country; on an average fourteen to fifteen thousand vehicles move per day on this highway. Iradatnagar $\left(26.9665^{\circ} \mathrm{N}, 78.0438^{\circ} \mathrm{E}\right)$ site is situtated $36 \mathrm{kms}$ far away from Agra city. Iradatnagar, sampling site is exclusively an agricultural area and contains large agricultural farms where most of the agricultural practices like field plowing, irrigation and biomass burning have been done. Traffic load at this site is very low but most of diesel vehicles ply on this site. Total 12,84,676 commercial and noncommercial vehicles are registered in Agra region. four major highways and two expressways pass through the city namely Agra-Jaipur Highway NH-21 (Old number NH-11), Agra-Gwalior Highway NH-44 (old number NH-3), Agra- Aligarh Highway NH 509 (old number NH-93), Agra-Delhi Highway NH-19 (old number $\mathrm{NH}-2$ ), Yamuna expressway (Delhi-Agra) and Agra-Lucknow expressway. These highways take a toll of nearly $10^{5}$ vehicles per day ${ }^{11}$.

\subsection{Sampling Protocol}

Sampling was conducted in the month of December to January 2017-18 using Cascade Impactor in combination with a 2 stage cut point $(2.5 \mu \mathrm{m}$ and $0.5 \mu \mathrm{m})$. Drycal DC-2 calibrator was used to calibrate the instruments (Bios International Corporation, NJ USA). In this study, PM samples were collected on $25 \mathrm{~mm}$ PTFE (Poly Tetra Fluor Ethylene) filters with pore size $0.5 \mu \mathrm{m}$ in two stage fractions $\left(\mathrm{PM}_{2.5-1.0} \& \mathrm{PM}_{1.0-}\right.$ $0.5)$. The instrument was fixed at breathing height above the ground level on tripod photographic stand. Pump was operated at 9 liters per minute and 54 samples were collected as per the Central Pollution Control Board guidelines (СРCB 2010). The PM concentration was calculated by dividing the difference in pre- and post-weight of filters by the sampled air volume (Rohra et al. 2018). Microbalance model No. (CAl-35) (Contech analytical balance) used for weighing of filters. The ambient parameter (carbon dioxide and temperature) were measured using Handy Air Quality monitor (TELAIRE). To keep the quality control all the glassware were cleaned by soaking in $2 \% \mathrm{HNO}_{3}$ overnight in follow up with rinsing it with deionized water. Half filter paper was used for the total concentration (through acid extraction) and the remaining was used for the soluble fraction (through ammonium acetate) (Varshny et al. 2015). Inductive Coupled Plasma-Optical Emission Spectroscopy was employed for multi-elemental analysis.

\subsection{Health Risk Analysis}

The four-stage method set by the USEPA (2009) was performed using all metal-bound particles between $\mathrm{PM}_{2.5-1.0}$ and $\mathrm{PM}_{1.0-0.5}$ in all the ambient sites for each receptor (children and adults).At the first, Hazards Quotient ( $\mathrm{HQ}$ ) values ( $\mathrm{Al}, \mathrm{Ni}$. Mn and $\mathrm{Cr}$ ) were calculated as non-carcinogenic effects whereas Excess cancer risk was calculated $(\mathrm{Pb}, \mathrm{Ni}$ and $\mathrm{Cr}(\mathrm{VI}))$ were calculated as carcinogenic elements. The risk of $\mathrm{Cr}(\mathrm{VI})$ was calculated as 1/7th of the total $\mathrm{Cr}$ concentration because $\mathrm{Cr}(\mathrm{VI})$ and $\mathrm{Cr}$ (III) exist in air with ratio of 1:6. (Hieu and Lee 2010). The chronic exposure concentration in the next step was calculated using the following formula (USEPA 2009).

$\mathrm{EC}=(\mathrm{CA} \times \mathrm{ET} \times \mathrm{EF} \times \mathrm{ED}) / \mathrm{AT}$. 
where: $\mathrm{EC}(\mu \mathrm{g} / \mathrm{m} 3)=$ exposure concentration; $\mathrm{CA}(\mu \mathrm{g} / \mathrm{m} 3)=$ concentration of pollutant in air; $\mathrm{ET}=$ exposure time (period over which a person exposed which was $24 \mathrm{~h} /$ day); $E F$ = exposure frequency (Taken as 350 days/year); $E D=$ exposure duration which was taken as 20 years and 6 years for adult and child respectively; $A T=$ that equals to ED in years $\times 365$ days/year $\times 24 \mathrm{~h} /$ day for non-carcinogens and LT (lifetime of 70 years) $\times 365$ days/year $\times 24 \mathrm{~h} /$ day for carcinogens. All the above default values were applied which are mentioned in (USEPA 2014). Eq. 2 and Eq. 3 was used for HQ and ELCR calculation respectively. (Taner et al. 2013)

$\mathrm{EC}=(\mathrm{HQ} /$ Toxicity Valuex $1000 \mu \mathrm{g} / \mathrm{mg})$

$E L C R=I U R \times E C$

IUR is defined as the upper bound Excess Lifetime Cancer Risk. Values of different metals for IUR and RfC were taken from USEPA 2009; IRIS.

\section{Results And Discussion}

\subsection{PM concentrations}

Comparison of Average Mass concentration of PM in different sampling sites is shown in Fig. 2. The average $\mathrm{PM}_{2.5-1.0}$ size fraction concentration in all the sampling sites was found higher 7-8 times than National Ambient Air Quality Standards $\left(60 \mu \mathrm{g} / \mathrm{m}^{3}\right)$. Average value of $\mathrm{PM}_{1.0-0.5}$ was found higher at Iradatnagar $\left(361.01 \mu \mathrm{g} / \mathrm{m}^{3}\right)$ comparison to $\mathrm{GLA}\left(313.47 \mu \mathrm{g} / \mathrm{m}^{3}\right)$. Present study result was good agreement with another study which was conducted near roadside $328.5 \pm 229.6 \mu \mathrm{g} / \mathrm{m}^{3}$ (Goyal and Khare 2009) $259.51 \pm 55.62 \mu \mathrm{g} / \mathrm{m}^{3}$ (Habil and Taneja 2011). Prasad et al. 2003 also reported commuter exposure, In Delhi $\mathrm{PM}_{5}$ concentrations was as high as $2860 \mu \mathrm{g} / \mathrm{m}^{3}$ and $810 \mu \mathrm{g} / \mathrm{m}^{3}$ for two wheelers and three wheeler respectively. Whereas the size fraction of $\mathrm{PM}_{2.5-1.0}$ was found higher at GLA $\left(350.92 \pm 171.28 \mu \mathrm{g} / \mathrm{m}^{3}\right)$ followed by Iradatnagar $\left(329.12 \pm 205 \mu \mathrm{g} / \mathrm{m}^{3}\right)$ site respectively. Results was found relatively similar with earlier studies (361.1 $\left.\pm 251.8 \mu \mathrm{g} / \mathrm{m}^{3}\right)$ (Goyal and Khare 2009), $\left(313 \pm 181 \mu \mathrm{g} / \mathrm{m}^{3}\right)$ (Das et al. 2015).In winters at rural area (Iradatnagar) combustion of agricultural residue and wood burning are important source of exposure to PM. (Agarwal et al. 2012; Rajput et al. 2014 ;). Biomass burning is the key component of $\mathrm{PM}_{2.5}$ in winter and secondary aerosol are the major sources of PM. (Kulshrestha et al. 2009). Over South Asia biomass/residential emissions are major contributor's to $P M_{2.5}$ which is responsible for burning of crop, wood and cow dung (Nagpure et al. 2014). High values of PM at GLA crossing may be due to high traffic intensity and industrial emission. Vehicle emerges as the most dominating source of PM and it is reported to contribute (5-90\%) Industrial emission is identified important contributor of fine particulate (1-58\%), on the other hand Mathura oil refinery and Firozabad glass industries along with a number of industrial units serves as a local pollution source (Kulshrestha et al. 2009). During the study period metrological parameters such as temperature ( $\left.14.07 \pm 2.84^{\circ} \mathrm{C}\right), \mathrm{CO}_{2}$ (506.15 \pm 17.85 PPM) and relative humidity $(77 \pm 9.56 \%)$ was recorded, during winter seasons atmosphere 
remains foggy and increase secondary aerosol formation which accumulate near ground surface and increase the level of PM (Prakash et al. 2018).

\subsection{Metal concentration in size segregated PM}

Figure 3 and Fig. 4tells the average concentrations of twelve elements for $\mathrm{PM}_{2.5-1.0} \& \mathrm{PM}_{1.0-0.5} . \mathrm{Ni}, \mathrm{Mn}, \mathrm{Cr}$, $\mathrm{Cu}, \mathrm{Mg}, \mathrm{Pb}$ were found higher at GLA followed by Iradatnagar for $\mathrm{PM}_{2.5-1.0}$ fraction. $\mathrm{Pb}$ and $\mathrm{Cu}$ contributed from vehicular emissions, come dominantly from wear of tire rather known engine combustion. Universally accepted sources like $\mathrm{Cu}, \mathrm{Pb}, \mathrm{Mn}, \mathrm{Ni}$ is attributed to Brake lining, fuel Additives and Combustion of heavy oil (Banerjee et al. 2015, Pant and Harrison. 2012). In India vehicular emissions is the key source of $\mathrm{Cu}, \mathrm{Ni}, \mathrm{Pb}, \mathrm{Zn}$ and $\mathrm{Mn}$ (Kulshrestha et al. 2009; Deshmukh et al. 2013) GLA site can be attributed to higher rate of brake abrasion and high traffic flow rate. $\mathrm{Cd}, \mathrm{Fe}, \mathrm{Al}, \mathrm{Ca}$ were higher at Iradatnagar sites followed by GLA. These are the crustal element which probable sources are resuspended road dust, metal smelter, incinerators and vehicular emission (Chueinta et al. 2000). Al, Ca and Fe are elements linked with crustal sources (Begum et al. 2004) probably un-paved road at rural traffic site is the main source of these tracer comparison to other site. Al, Ca is also emitted from Brick Klin(Begam et al. 2014) which is situated $9 \mathrm{~km}$. far away from rural site (Iradatnagar) and the key contributors of metal sources. Results showed the similar trend for size fraction $\mathrm{PM}_{1.0-0.5}$ excepting $\mathrm{Ba}$ and $\mathrm{Mn}$ which were higher at Iradatnagar. Iradatnagar is occupied with residential colonies and people generally use two stroke engine (bikes and scooters) comparatively four stroke engine (cars) to go offices, market and schools. Two stroke engine and fuel additives in two stroke engines are the main sources of $\mathrm{Zn}$ and $\mathrm{Ba}$ (Pant and Harrison 2012; Mansha et al. 2012). Elevated concentration of $\mathrm{Ni}, \mathrm{Mn}, \mathrm{Cr}, \mathrm{Cu}, \mathrm{Mg}, \mathrm{Pb}$ and Cd may be affected by industrial activities (Kulshrestha et al. 2009; Das et al. 2014; Banerjee et al. 2015). The average value of $\mathrm{Ca}, \mathrm{Cd}, \mathrm{Cu}, \mathrm{Fe}, \mathrm{Mg}, \mathrm{Ni}, \mathrm{Zn}$ was found higher for $\mathrm{PM}_{2.5-1.0}$ fraction while Al, $\mathrm{Ba}$, $\mathrm{Cr}, \mathrm{Mn}$, and $\mathrm{Pb}$ was higher for $\mathrm{PM}_{1.0-0.5}$ fraction. Light metal group (atomic number $<20$ and lower) like $\mathrm{Ca}, \mathrm{Mg}$ and $\mathrm{Al}$ was found higher at all sampling sites whereas Heavy metals (atomic number $>20$ ) group viz. $\mathrm{Cd}, \mathrm{Cu}, \mathrm{Fe}, \mathrm{Ni}, \mathrm{Zn}, \mathrm{Ba}, \mathrm{Cr}, \mathrm{Mn}, \mathrm{Pb}$ were found in low concentration compared to light metal group.52.46\% light metal found in $\mathrm{PM}_{2.5-1.0}$ and $56.68 \%$ in $\mathrm{PM}_{1.0-0.5}$ size fraction whereas heavy metals were $47.53 \%$ in $\mathrm{PM}_{2.5-1.0}$ and $43.31 \%$ was in $\mathrm{PM}_{1.0-0.5}$ size fraction.

\subsection{Bioavailability Index (BI)}

In the current study eleven metals revealed soluble mass concentration except $\mathrm{Ni}$ and $\mathrm{Mn}$ which were below the detection limits for Iradatnagar site. Metals are associated in the form of silicate, cement and doxidates in soluble fraction and that ought's to be extracted under hard acid conditions (Feng et al. 2009). The soluble fraction of metals is readily absorbed in respiratory system which possesses maximum risk to human health (Friberg et al. 1986). Bioavailability is the fraction of the total amount of a metal; which indicated overall physiological and toxic effects of a metal on biological systems (Olaniran et al. 2013). Mn causes various psychiatric and movement disorder. Long term exposure of Al associated with pulmonary fibrosis and pulmonary injury. Inflammation has been caused by transition 
metal. $\mathrm{Cu}, \mathrm{Zn}$ is associated as vomiting, diarrhea, liver and kidney failure and anemia. Long time exposure of $\mathrm{Pb}$ is associated with heme-biosynthesis, nervous system and kidney failure. The calculated values of BI for metal are shown in Fig. (5) for size fraction PM 2.5-1.0 and Fig. (6) for size fraction $\mathrm{PM}_{1.0-0.5}$. Results revels that bigger particles showed the higher bioavailability in comparison with smaller size fraction. In this study it was found that $\mathrm{PM}_{2.5-1.0}$ size fraction has more mobile and bioaccessible chemical species compare to $\mathrm{PM}_{1.0-0.5}$. Average bioavailability results for both size fractions was found higher for Iradatnagar while it was least for GLA. The BI of metals in $\mathrm{PM}_{2.5-1.0}$ and $\mathrm{PM}_{1.0-0.5}$ ranged between $5.12-6.46 \%$ and $4.56-7.055 \%$ respectively at both sites. On the basis of $\mathrm{BI}$ values metals can be categorized as less bioavailability when $\mathrm{BI}<30 \%$; medium bioavailability when $30 \%<\mathrm{BI}<$ $50 \%$ and high bioavailability when $\mathrm{BI}>50 \%$ (Sah et al. 2017). The calculated $\mathrm{BI}$ values are present in Fig. 6, 7. Higher Bls are considered to be physiologically active and pose more risks to individuals. In the present study at both size fraction all metals were found Low bioavailable except Al (33.01\%), Ca (34.23\%) and $\mathrm{Fe}(35.00 \%)$ which was found medium Bioavailability for $\mathrm{PM}_{2.5-1.0}$. Results of $\mathrm{Cr}, \mathrm{Ca}, \mathrm{Mn}$ Matched with Jiang et al. $\mathbf{2 0 1 5}$ whereas for Cd BI showed similarity with study of Espinosa et al. 2002 conducted in spain. Result of $\mathrm{Pb}$ and $\mathrm{Zn}$ was found similar with Rohra et al. $\mathbf{2 0 1 8}$ However the results of $\mathrm{Al}, \mathrm{Ba}, \mathrm{Cu}, \mathrm{Mn}$ and $\mathrm{Fe}$ was contradicts with earlier studies found contradict with study results of Jiang et al. 2015; Rohra et al. 2018. This is probably because the different methods were used for extraction and acid digestion (i.e. the concentration and matrix of acid) among the studies, which create differences in the recovery capacity for metals with different chemical states.(Espinosaetal.2002).

\subsection{Health Risk Estimation}

Present study makes novel tactics to assess health risk impersonated by different size fraction of PM in term of different types of traffic junction. For both receptor (adult and child) carcinogenic (ELCR) and noncarcinogenic risk (HQ), is calculated in term of different traffic sites. When $H Q \leq 1$ indicates no adverse health effects and $\mathrm{HQ} \geq 1$ indicates likely adverse health effects. The average value of $\mathrm{HQs}$ for $\mathrm{PM}_{2.5-1.0}$ and $\mathrm{PM}_{1.0-0.5}$ size fraction was found higher for $\operatorname{GLA}(7.95,9.50)$ comparison to Iradatnagar $(1.74,3.90)$. The results are found to accord with (Prakash et al., 2018) (Fig. 7a, Fig. 7b) values for smaller size fraction was found slightly higher. $\mathrm{Mn}$ and $\mathrm{Ni}$ was below the limit at Iradatnagar site for $\mathrm{PM}_{2.5-1.0}$ size fraction while Ni for $\mathrm{PM}_{1.0-0.5}$ size. Results of the present study were found similar with Liu et al., 2015 in Changsha. HQs trend in term of metals for $\mathrm{PM}_{2.5-1.0}$ and $\mathrm{PM}_{1.0-0.5}$ were followed as $\mathrm{Cr}>\mathrm{Ni}>$ $\mathrm{Al}>\mathrm{Mn}$ our results found similar with (Khan et al., 2016). Ni found higher than $\mathrm{Mn}$ for $\mathrm{PM}_{2.5-1.0}$ size fraction but it contradicts with $\mathrm{PM}_{1.0-0.5}$. Cr was found higher than Al (Rohra et al., 2018), (Niu et al., 2015).It should be noted that long-term exposure to vehicle exhaust, emissions from wear and tear and re-suspended road dust threat to commuters, pedestrian and People working in commercial establishments near road.

\subsection{Excess Life Cancer Risk Values (ELCR)}


Carcinogenic risk for metals was calculated in both size fractions $\left(\mathrm{PM}_{2.5-1.0}\right.$ and $\left.\mathrm{PM}_{1.0-0.5}\right)$. Cr posed highest non-carcinogenic risk as well as cancerous risk; result was found higher for $\mathrm{Cr}(\mathrm{VI})$ comparison to other metals. It was found that result was higher than the acceptable limit (USEPA 2009) for both adult and children $\mathrm{h}$. The trend of metal for carcinogenicity followed as $\mathrm{Cr}(\mathrm{VI})>\mathrm{Pb}>\mathrm{Ni}$ for both size fractions. $\mathrm{Cr}(\mathrm{VI})$ value for ELCR was found similar with earlier study (Hieu and Lee et al. 2010; Massey et al. 2013 and Sah et al. 2017). Highest values for carcinogenicity were found higher for GLA to Iradatnagar site. This study conducted to find out the existing link between size fraction and its effect on human health. It was observed that overall non-carcinogenic risk (Fig. 7a,b) and ELCR (Fig. 8a, b, C, d) differ by different size fraction. Values of $H Q$ and ELCR was found higher at smaller size fraction $\left(\mathrm{PM}_{1.0-0.5}>\mathrm{PM}_{2.5-1.0}\right)$ for both sampling sites. The trend of average value of carcinogenic risk factor was found two times higher than prescribed limit $\left(1 * 10^{6}\right)$ given by USEPA which infers higher risk posed to the locales in our study report furthermore, values of ELCR was found higher for adults (2 times) comparison to children (1.5 times).

\subsection{Principal Component Analysis}

PCA, an extension of the correlation analysis, is used to distinguish and validate the major sources of potential pollution in the study area. PCA results are shown in Table 1 and Table 2 for Iradatnagar and GLA sampling sites, which they are within Factor 1 with the highest eigenvalue of 7.13. Factor loads of

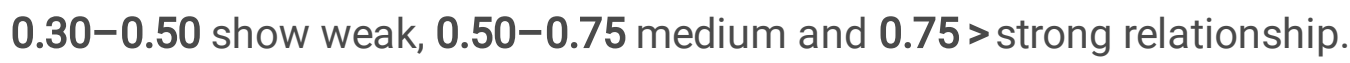


Table 1

PCA for Iradatnagar Site.

\begin{tabular}{|lllll|}
\hline \multicolumn{5}{|c|}{ Iradatnagar Rotated Component Matrix } \\
\hline \multicolumn{5}{|c|}{ Component } \\
\cline { 2 - 5 } & Factor 1 & Factor 2 & Factor 3 & Factor 4 \\
\hline $\mathrm{Al}$ & -.85 & -.01 & .12 & -.21 \\
$\mathrm{Ba}$ & .09 & .04 & .06 & .89 \\
$\mathrm{Ca}$ & .64 & .19 & -.08 & .01 \\
\hline $\mathrm{Cd}$ & .39 & .60 & .03 & .30 \\
\hline $\mathrm{Cr}$ & -.88 & -.01 & .03 & -.07 \\
\hline $\mathrm{Cu}$ & .90 & -.02 & .03 & .11 \\
\hline $\mathrm{Fe}$ & .66 & .04 & -.27 & .03 \\
\hline $\mathrm{Mg}$ & .00 & .06 & .86 & .00 \\
\hline $\mathrm{Mn}$ & -.29 & -.09 & .65 & .01 \\
\hline $\mathrm{Ni}$ & .76 & -.09 & -.10 & -.05 \\
\hline $\mathrm{Pb}$ & .06 & -.83 & .13 & -.00 \\
\hline $\mathrm{Zn}$ & -.08 & .60 & .23 & -.47 \\
\hline Eigen Value & 4.29 & 1.51 & 1.25 & 1.02 \\
\hline Cumulative & 33.60 & 46.04 & 57.49 & 67.38 \\
\hline$\%$ Variance & 33.60 & 12.43 & 11.45 & 9.89 \\
\hline
\end{tabular}


Table 2

PCA for For GLA Site.

\begin{tabular}{|llll|}
\hline \multicolumn{4}{|c|}{ GLA Rotated Component Matrix } \\
\hline \multicolumn{4}{|c|}{ Component } \\
\cline { 2 - 4 } & Factor 1 & Factor 2 & Factor 3 \\
\hline $\mathrm{Al}$ & -.81 & -.08 & .04 \\
\hline $\mathrm{Ba}$ & -.15 & -.20 & .86 \\
\hline $\mathrm{Ca}$ & .96 & .06 & -.09 \\
\hline $\mathrm{Cd}$ & .14 & .63 & -.08 \\
\hline $\mathrm{Cr}$ & -.63 & -.27 & -.40 \\
\hline $\mathrm{Cu}$ & .85 & .03 & -.15 \\
\hline $\mathrm{Fe}$ & .95 & .00 & -.16 \\
\hline $\mathrm{Mg}$ & .90 & .01 & .14 \\
\hline $\mathrm{Mn}$ & -.81 & -.10 & .23 \\
\hline $\mathrm{Ni}$ & .43 & -.49 & -.26 \\
\hline $\mathrm{Pb}$ & .09 & .77 & -.13 \\
\hline $\mathrm{Zn}$ & -.89 & -.07 & .06 \\
\hline Eigen Value & 6.27 & 1.36 & 1.07 \\
\hline Cumulative & 51.34 & 62.94 & 72.59 \\
\hline$\%$ Variance & 51.34 & 11.59 & 9.65 \\
\hline
\end{tabular}

For Iradatnagar KMO value for the study was found to be 0.78 which is sufficient to apply PCA. As a result of PCA test, 4 factors with eigen value $>1$ were calculated which explained $67.38 \%$ of total variance. The first factor constitutes $33.6 \%$ of the total variance. In this factor $\mathrm{Cu}$ and Ni Showed Strong Load while $\mathrm{Ca}$ and Fe showed Moderate load. Al and $\mathrm{Cr}$ were found to be in Negative loadings. Thus the 1 component with metal loading of $\mathrm{Al}, \mathrm{Ca}, \mathrm{Cr}, \mathrm{Cu}, \mathrm{Fe}$ and $\mathrm{Ni}$ was influenced by vehicular as well as industrial emission (Karar et al., 2006; Kulshrestha et al., 2009). The second factor constitutes of a total of $12.43 \%$ of the total variance where $\mathrm{Cd}$ and $\mathrm{Zn}$ showed moderate load and $\mathrm{Pb}$ were found to be in Negative load. Thus the 2 components having metal loadings of $\mathrm{Cd}, \mathrm{Zn}$, and $\mathrm{Pb}$ possible source of these metals could be abrasion of brake pad and engine parts (Karar et al., 2006). The third factor constitutes of total $11.45 \%$ of the total variance. In this factor, $\mathrm{Mg}$ showed high loadings while $\mathrm{Mn}$ showed moderate loadings. Thus the 3 components having metal loadings of $\mathrm{Mg}$ and $\mathrm{Mn}$ were influenced by sources like industries, resuspended road dust and long-range transported dust (Lee \& Von Lehmden, 1973; Sun et al., 2004). The fourth factor constitutes of total $9.89 \%$ of the total variance where Ba showed high loading indicating, 
Vehicular tailpipe emission, brake and tyre wear are primary sources of $\mathrm{Ba}$ in atmosphere (Monachi \& Bargagli, 1997; Goddard et al., 2019). For the site GLA KMO value for the study was found to be 0.888 which is sufficient to apply PCA. As a result of PCA test, 3 factors with eigen value $>1$ were calculated which explained $72.59 \%$ of total variance. The first factor consititues $51.34 \%$ of the total variance. In this factor $\mathrm{Ca}, \mathrm{Cu}, \mathrm{Fe}$, and $\mathrm{Mg}$ Showed Strong Load while Al, $\mathrm{Cr}, \mathrm{Mn}$ and $\mathrm{Zn}$ were found to be in Negative loadings. Thus the 1 component with metal loading of $\mathrm{Ca}, \mathrm{Cu}, \mathrm{Fe}, \mathrm{Mg}, \mathrm{Al}, \mathrm{Cr}, \mathrm{Mn}$ and $\mathrm{Zn}$ was influenced by re-suspension of road dust including tailpipe emission from vehicle as well as non-exhaust emission from vehicular activities (Daun et al., 2013; Hjortenkrans et al., 2007; Lin et al 2020). The second factor consititues of a total of $11.59 \%$ of the total variance where $\mathrm{Pb}$ showed High loading and $\mathrm{Cd}$ with moderate load. Thus the 2 components having metal loadings of $\mathrm{Pb}$ and $\mathrm{Cd}$ were influenced by brake pad and engine parts (Karar et al., 2006). The third factor constitutes of total $9.65 \%$ of the total variance. In this factor, only Ba was found in high loadings which indicates that it might be influenced by vehicular tailpipe emission, brake and tyre wear are primary sources of Ba in atmosphere (Monachi \& Bargagli, 1997; Goddard et al., 2019).

\section{Conclusion}

Results of the present study reveals a very high average concentration of PM found at traffic sites crossing posing high risk of particulate pollution. In term of metals anthropogenic sources (vehicular emissions, oil combustion, coal combustion, Incineration) have stronger contribution to metals emission. The study showed that health risk through inhalation of PM is not negligible to commuters, pedestrian and people living near road side. Higher average percentage of bioavailability was found for

Bigger $\left(\mathrm{PM}_{2.5-1.0}\right)$ size fraction comparison to smaller size $\left(\mathrm{PM}_{1.0-0.5}\right)$. Metal toxicity has proven to be major threats and associated with several health risks. Metal toxicity is harmful for the human body and its proper functioning. The calculated values of $\mathrm{HQ}$ was found higher for all metals ( $\mathrm{Ni}, \mathrm{Mn}, \mathrm{Cr}$ and $\mathrm{Al}$ ) which has adverse health effect, it was observed that high traffic intensity have greater influences on these metals, the trend obtained was GLA > Iradatnagar. It shows that traffic emission has higher impact on air quality which isDetroiting the health of human being. Highest value of ELCR was found for $\mathrm{Cr}(\mathrm{VI})$ the trend of average value of carcinogenic risk factor was found $\sim 2$ times higher than prescribed limit $\left(1 * 10^{6}\right)$ for adult and child respectively.

\section{Declarations}

\section{Acknowledgements}

Authors are thankful to the Head of the Department, Department of Chemistry, GLA University Mathura and Department of Chemistry, Institute of Basic Science, Dr B R Ambedkar University, Agra for lab facilities and infrastructural support.

\section{Conflict of Interest}


There is no conflict of interest by authors

\section{References}

Agarwal, R., Awasthi, A., Singh, N., Gupta, P. K., Mittal, S. K., (2012) Effects of exposure to rice-crop residue burning smoke on pulmonary functions and Oxygen Saturation level of human beings in Patiala (India). Science of the Total Environmental429: 161-166.

Banerjee, T., Murari, V., Kumar, M., \&Raju, M. P. (2015). Source apportionment of airborne particulates through receptor modeling: Indian scenario. Atmospheric Research, 164, 167-187.

Begum, B. A., Kim, E., Biswas, S. K., \&Hopke, P. K. (2004).Investigation of sources of atmospheric aerosol at urban and semi-urban areas in Bangladesh.Atmospheric Environment, 38(19), 3025-3038.

Begum, B. A., Nasiruddin, M., Randall, S., Sivertsen, B., \&Hopke, P. K. (2014).Identification and apportionment of sources from air particulate matter at urban environments in Bangladesh.British Journal of Applied Science \& Technology, 4 (27), 3930-3955.

Brugge, D., Durant, J. L., \&Rioux, C. (2007). Near-highway pollutants in motor vehicle exhaust: a review of epidemiologic evidence of cardiac and pulmonary health risks. Environmental health, 6(1), 23.

Chueinta, W., Hopke, P. K., \&Paatero, P. (2000).Investigation of sources of atmospheric aerosol at urban and suburban residential areas in Thailand by positive matrix factorization. Atmospheric Environment, 34(20), 3319-3329.

$\mathrm{CPCB}, 2010$. Central pollution control board, air quality monitoring, emission inventory and source apportionment study for Indian cities, National Summary Report the Central Pollution Control Board, New Delhi, India.

Das, R., Khezri, B., Srivastava, B., Datta, S., Sikdar, P. K., Webster, R. D., \& Wang, X. (2015). Trace element composition of PM2. 5 and PM10 from Kolkata-a heavily polluted Indian metropolis.Atmospheric Pollution Research, 6(5), 742-750.

Daun, K. J., Sipkens, T. A., Titantah, J. T., \& Karttunen, M. (2013). Thermal accommodation coefficients for laser-induced incandescence sizing of metal nanoparticles in monatomic gases. Applied Physics B, 112(3), 409-420.

Delfino, R. J., Staimer, N., Tjoa, T., Gillen, D., Kleinman, M. T., Sioutas, C., \& Cooper, D. (2008).Personal and ambient air pollution exposures and lung function decrements in children with asthma. Environmental health perspectives, 116(4), 550-558.

Deshmukh, D. K., Deb, M. K., \&Mkoma, S. L. (2013). Size distribution and seasonal variation of sizesegregated particulate matter in the ambient air of Raipur city, India.Air Quality, Atmosphere \& Health, 6(1), 259-276. 
Espinosa, A. J. F., Rodríguez, M. T., de la Rosa, F. J. B., \& Sánchez, J. C. J. (2002). A chemical speciation of trace metals for fine urban particles. Atmospheric Environment, 36(5), 773-780.

Feng, X. D., Dang, Z., Huang, W. L., \& Yang, C. (2009). Chemical speciation of fine particle bound trace metals. International Journal of Environmental Science \& Technology, 6(3), 337-346.

Friberg, L., Nordberg, G. F., \&Vouk, V. B. (1986). Handbook on the toxicology of metals (2nd ed., pp. 5-6). Amsterdam: Elsevier Science and Technology.

Goddard, S. L., Williams, K. R., Robins, C., Butterfield, D. M., \& Brown, R. J. (2019). Concentration trends of metals in ambient air in the UK: a review. Environmental monitoring and assessment, 191(11), 1-16.

Guttikunda, S. K., \& Mohan, D., (2014). Re-fueling road transport for better air quality in India.Energy Policy, 68, 556-561.

Goyal, R., \&Khare, M. (2009). Indoor-outdoor concentrations of RSPM in classroom of a naturally ventilated school building near an urban traffic roadway. Atmospheric Environment, 43(38), 6026-6038.

Habil, M., \&Taneja, A. (2011). Children's exposure to indoor particulate matter in naturally ventilated schools in India. Indoor and Built Environment, 20(4), 430-448.

Hieu, N. T., \& Lee, B. K. (2010). Characteristics of particulate matter and metals in the ambient air from a residential area in the largest industrial city in Korea.Atmospheric Research, 98(2-4), 526-537.

Hildemann, L. M., Markowski, G. R., Jones, M. C., \& Cass, G. R. (1991).Submicrometer aerosol mass distributions of emissions from boilers, fireplaces, automobiles, diesel trucks, and meat-cooking operations.Aerosol Science and Technology, 14(1), 138-152.

Hjortenkrans, D. S., Bergbäck, B. G., \& Häggerud, A. V. (2007). Metal emissions from brake linings and tires: case studies of Stockholm, Sweden 1995/1998 and 2005. Environmental science \& technology, 41(15), 5224-5230.

http://www.motorindiaonline.in/commercial-vehicles/indian-cv-industry-in-full-throttle/ accessed on 25.8.18

IRIS (Integrated Risk Assessment System), 1995. United States Environmental Protection Agency. www.epa.gov/IRIS, Accessed date: 11 November 2016.

Jiang, S.Y., Kaul, D.S., Yang, F., Sun, L., Ning, Z., 2015. Source apportionment and water solubility of metals in size segregated particles in urban environments. Sci. Total Environ. 533, 347-355.

Karar, K., Gupta, A. K., Kumar, A., \& Biswas, A. K. (2006). Characterization and identification of the sources of chromium, zinc, lead, cadmium, nickel, manganese and iron in PM 10 particulates at the two sites of Kolkata, India. Environmental Monitoring and Assessment, 120(1), 347-360. 
Karagulian, F., Belis, C. A., Dora, C. F. C., Prüss-Ustün, A. M., Bonjour, S., Adair-Rohani, H., \&Amann, M. (2015). Contributions to cities' ambient particulate matter (PM): A systematic review of local source contributions at global level. Atmospheric environment, 120, 475-483.

Khan, M. F., Latif, M. T., Saw, W. H., Amil, N., Nadzir, M. S. M., Sahani, M., ... \& Chung, J. X. (2016). Fine particulate matter in the tropical environment: monsoonal effects, source apportionment, and health risk assessment. Atmospheric Chemistry and Physics, 16(2), 597-617.

Kloog, I. (2016). Fine particulate matter (PM2. 5) association with peripheral artery disease admissions in northeastern United States. International journal of environmental health research, 26(5-6), 572-577.

Kulshrestha, A., Satsangi, P. G., Masih, J., \&Taneja, A. (2009).Metal concentration of PM2.5 and PM10 particles and seasonal variations in urban and rural environment of Agra, India.Science of the Total Environment, 407(24), 6196-6204.

Lee Jr, R. E., \& Von Lehmden, D. J. (1973). Trace metal pollution in the environment. Journal of the Air Pollution Control Association, 23(10), 853-857.

Lin, Y. C., Hsu, S. C., Lin, S. H., \& Huang, Y. T. (2020). Metallic elements emitted from industrial sources in Taiwan: Implications for source identification using airborne PM. Atmospheric Pollution Research, 11(4), 766-775.

Liu, X., Zhai, Y., Zhu, Y., Liu, Y., Chen, H., Li, P., ...\&Zeng, G. (2015). Mass concentration and health risk assessment of heavy metals in size-segregated airborne particulate matter in Changsha. Science of the Total Environment, 517, 215-221.

Mansha, M., Ghauri, B., Rahman, S., \& Amman, A. (2012).Characterization and source apportionment of ambient air particulate matter (PM2. 5) in Karachi. Science of the total environment, 425, 176-183.

Massey, D. D., Kulshrestha, A., \&Taneja, A. (2013).Particulate matter concentrations and their related metal toxicity in rural residential environment of semi-arid region of India.Atmospheric Environment, 67, 278-286.

Monaci, F., Bargagli, R., \& Gasparo, D. (1997). Air pollution monitoring by lichens in a small medieval town of central Italy. Acta Botanica Neerlandica, 46(4), 403-412.

Nagpure, A. S., Gurjar, B. R., \& Martel, J. C. (2014). Human health risks in national capital territory of Delhi due to air pollution. Atmospheric Pollution Research, 5(3), 371-380.

Niu, L., Ye, H., Xu, C., Yao, Y., \& Liu, W. (2015).Highly time-and size-resolved fingerprint analysis and risk assessment of airborne elements in a megacity in the Yangtze River Delta, China.Chemosphere, 119, 112121. 
Oberdorster, G., (2001). Pulmonary effects of inhaled ultrafine particles. Int. Arch. Occup. Environ. Health 74, 1-8 approach to indoor air pollution. Health Hum. Rights 15 (2), 160e167.

Olaniran, A., Balgobind, A., \&Pillay, B. (2013). Bioavailability of heavy metals in soil: impact on microbial biodegradation of organic compounds and possible improvement strategies. International journal of molecular sciences, 14(5), 10197-10228.

Pant, P., \& Harrison, R. M. (2012). Critical review of receptor modelling for particulate matter: a case study of India. Atmospheric Environment, 49, 1-12.

Pope III, C. A., Burnett, R. T., Thun, M. J., Calle, E. E., Krewski, D., Ito, K., \& Thurston, G. D. (2002). Lung cancer, cardiopulmonary mortality, and long-term exposure to fine particulate air pollution.Journal of American Medical Association, 287(9), 1132-1141.

Prakash, J., Lohia, T., Mandariya, A. K., Habib, G., Gupta, T., \& Gupta, S. K. (2018). Chemical characterization and quantitativ e assessment of source-specific health risk of trace metals in PM 1.0 at a road site of Delhi, India. Environmental Science and Pollution Research, 25(9), 8747-8764.

Prasad, R.K., Ravi Shankar, V., Saksena, S., 2003.Daily exposure to air pollution in indoor. Outdoor, -Veh. Micro-Environments: A Pilot Study Delhi, 57, 1-23.

Rajput, P., Sarin, M., Sharma, D., Singh, D., 2014. Characteristics and emission budget of carbonaceous species from post-harvest agricultural-waste burning in source region of the indo-gangetic plain. Tellus $B$, 66.

Rohra, H., Tiwari, R., Khandelwal, N., \&Taneja, A. (2018). Mass distribution and health risk assessment of size segregated particulate in varied indoor microenvironments of Agra, India-A case study. Urban climate, 24, 139-152.

RTI (2008) Research Triangle Institute (RTI), Standard Operating Procedure for Particulate Matter Gravimetric Analysis.

Sah, D., Verma, P. K., Kumari, K. M., \&Lakhani, A. (2017). Chemical partitioning of fine particle-bound As, $\mathrm{Cd}, \mathrm{Cr}, \mathrm{Ni}, \mathrm{Co}, \mathrm{Pb}$ and assessment of associated cancer risk due to inhalation, ingestion and dermal exposure. Inhalation toxicology, 29(11), 483-493.

Schwartz, J., Dockery, D. W., \&Neas, L. M. (1996). Is daily mortality associated specifically with fine particles? Journal of the Air \& Waste Management Association, 46(10), 927-939.

Singh, N., Murari, V., Kumar, M., Barman, S. C., \& Banerjee, T. (2017). Fine particulates over South Asia: review and meta-analysis of PM2. 5 source apportionment through receptor model. Environmental pollution, 223, 121-136. 
Singh, P., Saini, R., \&Taneja, A. (2014).Physicochemical characteristics of PM2. 5: Low, middle, and highincome group homes in Agra, India-a case study. Atmospheric Pollution Research, 5(3), 352-360.

Srimuruganandam, B., \&Nagendra, S. S. (2012). Application of positive matrix factorization in characterization of PM10 and PM2.5 emission sources at urban roadside.Chemosphere, 88(1), 120-130.

Srivastava, A., Gupta, S., \& Jain, V. K. (2009). Winter-time size distribution and source apportionment of total suspended particulate matter and associated metals in Delhi. Atmospheric Research, 92(1), 88-99.

Srivastava, R. K., \&Sarkar, R. (2017).Suspended Particulate Matter Pollution in Jabalpur: A Case Study.International Journal of Plant, Animal and Environmental Sciences, 7(1), 101-108.

Sun, Y., Zhuang, G., Wang, Y., Han, L., Guo, J., Dan, M., ... \& Hao, Z. (2004). The air-borne particulate pollution in Beijing-concentration, composition, distribution and sources. Atmospheric Environment, 38(35), 5991-6004.

Taner, S., Pekey, B., \&Pekey, H. (2013). Fine particulate matter in the indoor air of barbeque restaurants: Elemental compositions, sources and health risks. Science of the total environment, 454, 79-87.

Thorpe, A., \& Harrison, R. M. (2008). Sources and properties of non-exhaust particulate matter from road traffic: a review. Science of the total environment, 400(1-3), 270-282.

Tiwari, R., Singh, P. P., \&Taneja, A. (2020).Chemical Characterization of Particulate Matter at Traffic Prone Roadside Environment in Agra, India. Pollution, 6(2), 247-262.

USEPA (U.S. Environmental Protection Agency), (1998) Quality assurance guidance document 2.12: monitoring $\mathrm{PM}_{2.5}$ in ambient air using designated reference or class I equivalent methods. National Exposure Research Laboratory, Research Triangle Park, NC.

USEPA, 2009. Risk Assessment Guidance for Superfund: Volume I-Human Health Evaluation Manual (Part F, Supplemental Guidance for Inhalation Risk Assessment). (Washington D.C.).

USEPA, 2014. Human Health Evaluation Manual, Supplemental Guidance: Update of Standard Default Exposure Factors, OSWER Directive 9200.1-120, Feb 6, 2014,U.S. Environmental Protection Agency, Washington D.C., pp. 20460.

Varshney, P., Saini, R., \&Taneja, A. (2015). Trace element concentration in fine particulate matter (PM 2.5) and their bioavailability in different microenvironments in Agra, India: a case study. Environmental geochemistry and health, 38(2), 593-605.

Villalobos, A. M., Amonov, M. O., Shafer, M. M., Devi, J. J., Gupta, T., Tripathi, S. N., ...\&Schauer, J. J. (2015). Source apportionment of carbonaceous fine particulate matter (PM2. 5) in two contrasting cities across the Indo-Gangetic Plain.Atmospheric Pollution Research, 6(3), 398-405. 
Wallner, P., Hutter, H. P., \&Moshammer, H. (2014). Worldwide associations between air quality and health end-points: Are they meaningful?. International journal of occupational medicine and environmental health, 27(5), 716-721.

WHO, 2016. 7 Million Premature Deaths Annually Linked to air Pollution. World Health Organization, Geneva, Switzerland Access at. http://www.who.int/mediacentre/news/releases/ 2014/air-pollution/

Yu, L., Wang, G., Zhang, R., Zhang, L., Song, Y., Wu, B., ...\& Chu, J. (2013). Characterization and source apportionment of PM2.5 in an urban environment in Beijing.Aerosol and Air Quality Research, 13(2), 574583.

Figures

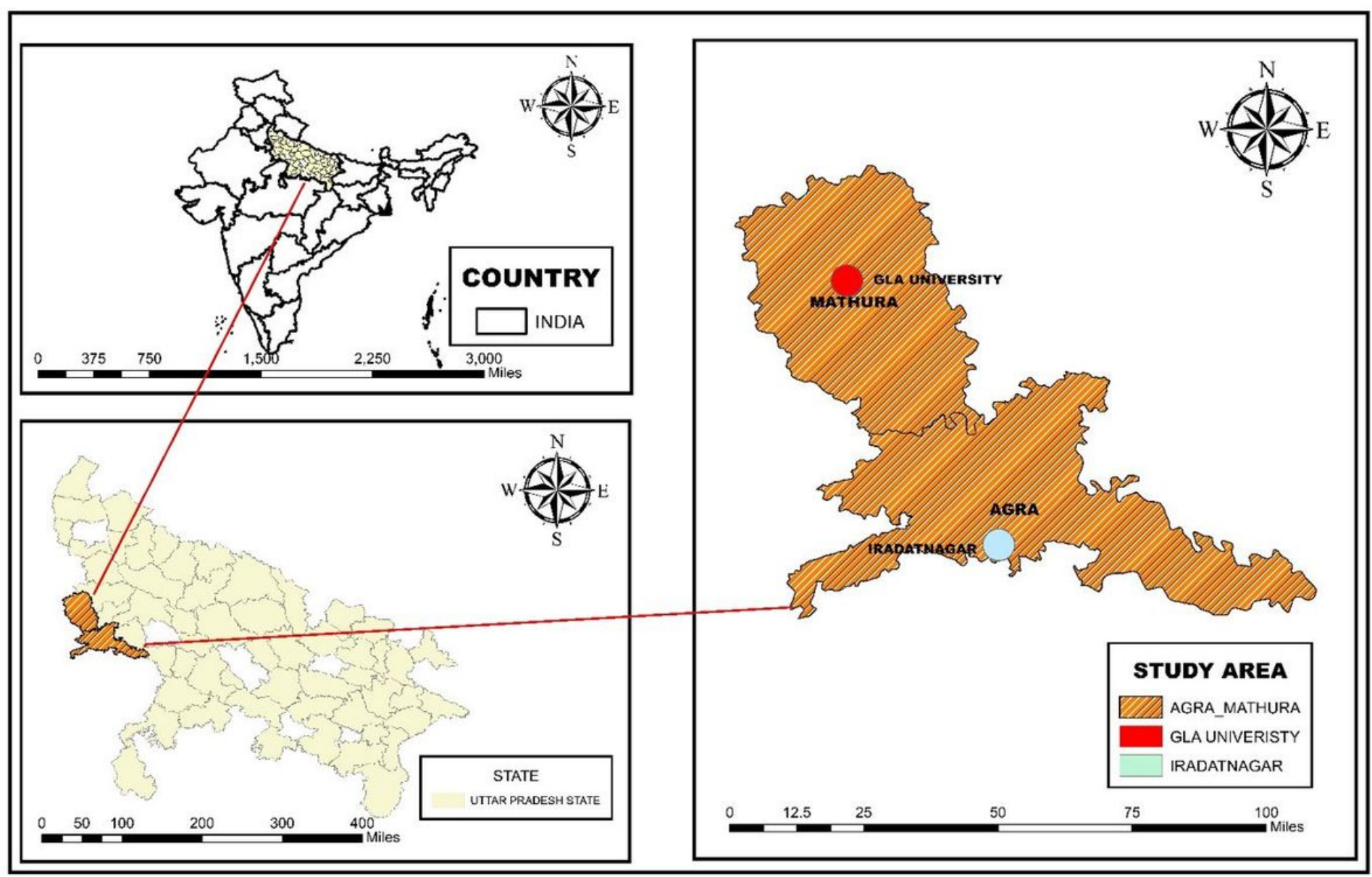

Figure 1

Map of India showing sampling sites. 


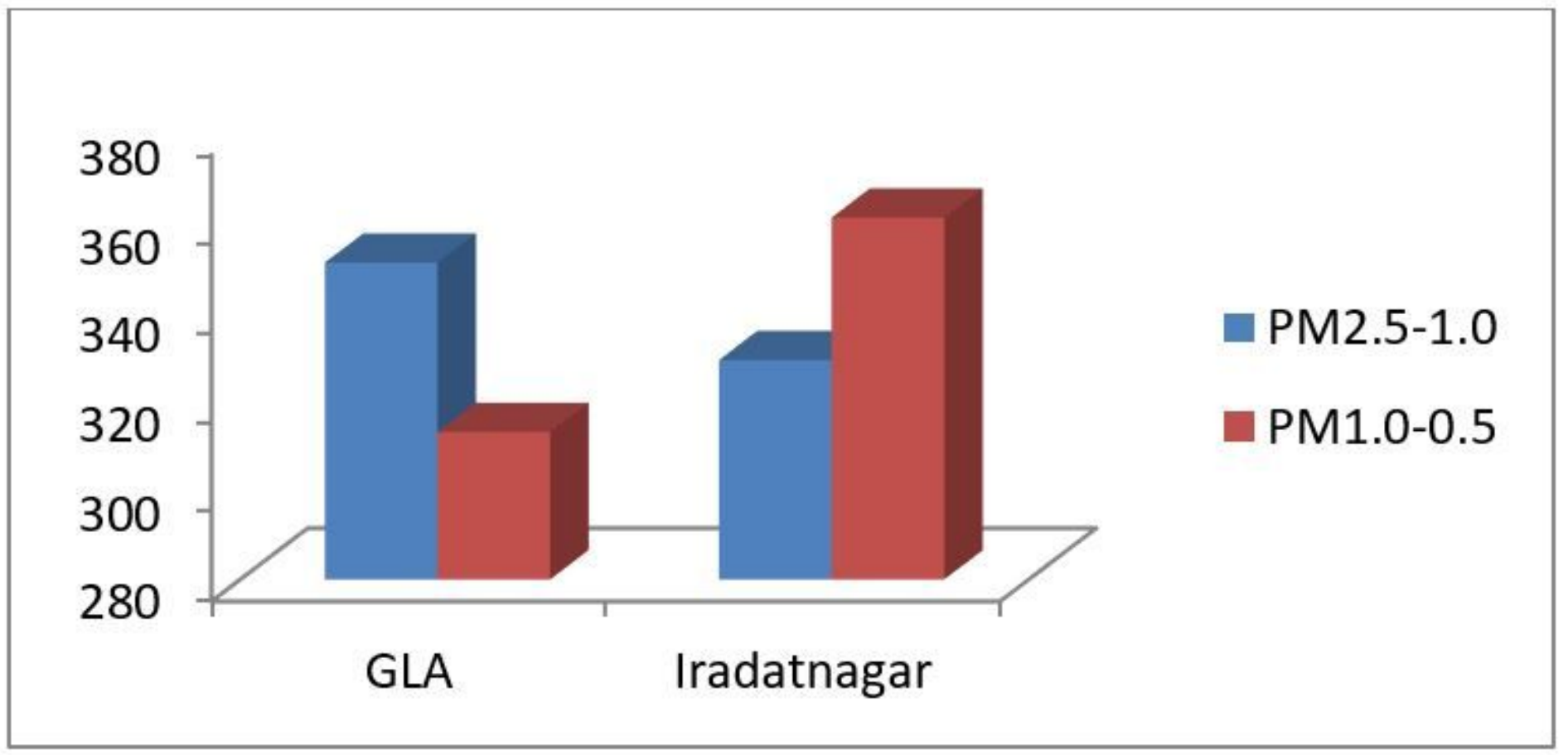

Figure 2

Comparison of Average Mass concentration of PM in different sampling site. (Values in $\mu \mathrm{g} / \mathrm{m} 3$ )

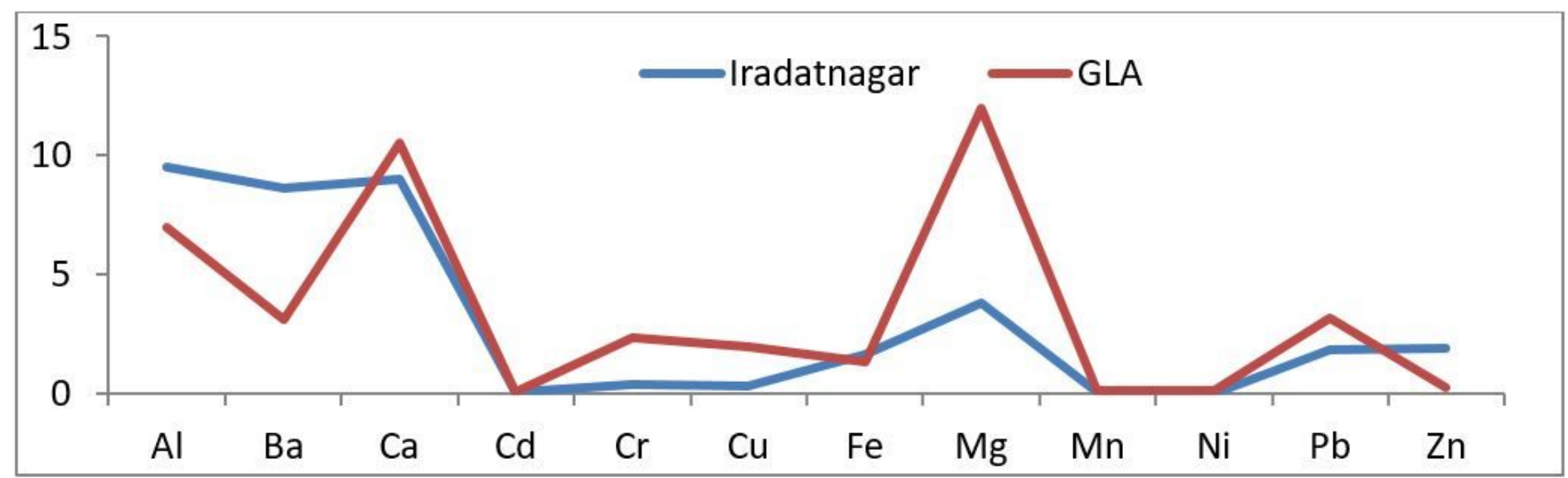

Figure 3

Comparison of Average concentration of metalsin PM2.5-1.0at different sampling site.(Values in $\mu \mathrm{g} / \mathrm{m} 3$ ) 


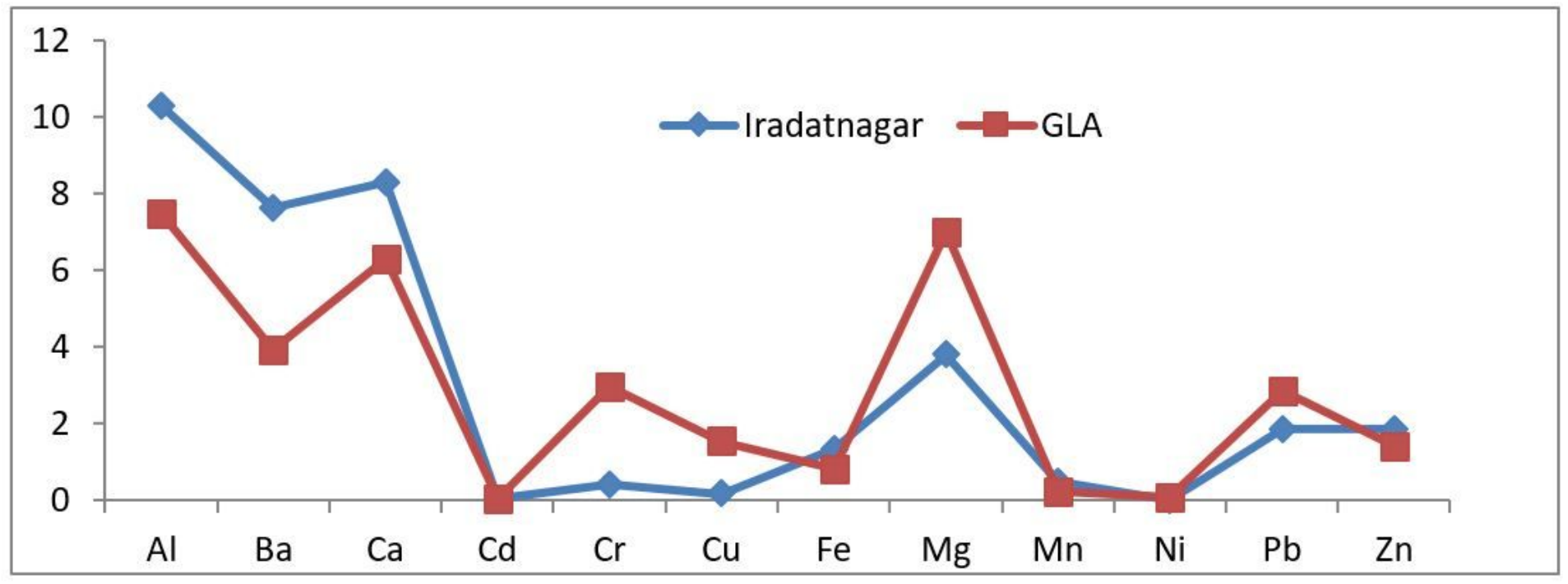

Figure 4

Comparison of Average concentration of metals in PM1.0-0.5 at different sampling site.(Values in $\mu \mathrm{g} / \mathrm{m} 3)$

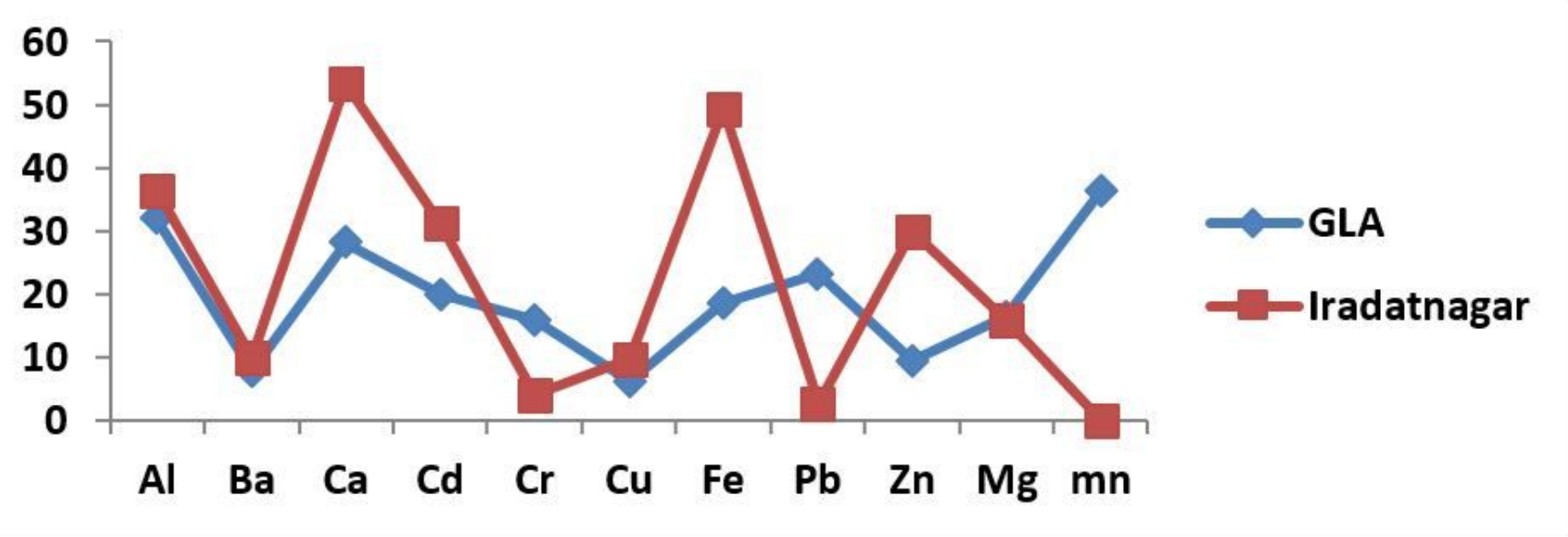

\section{Figure 5}

Bioavailability Index of metalsin PM2.5-1.0at different sampling site. (Values in \%) 


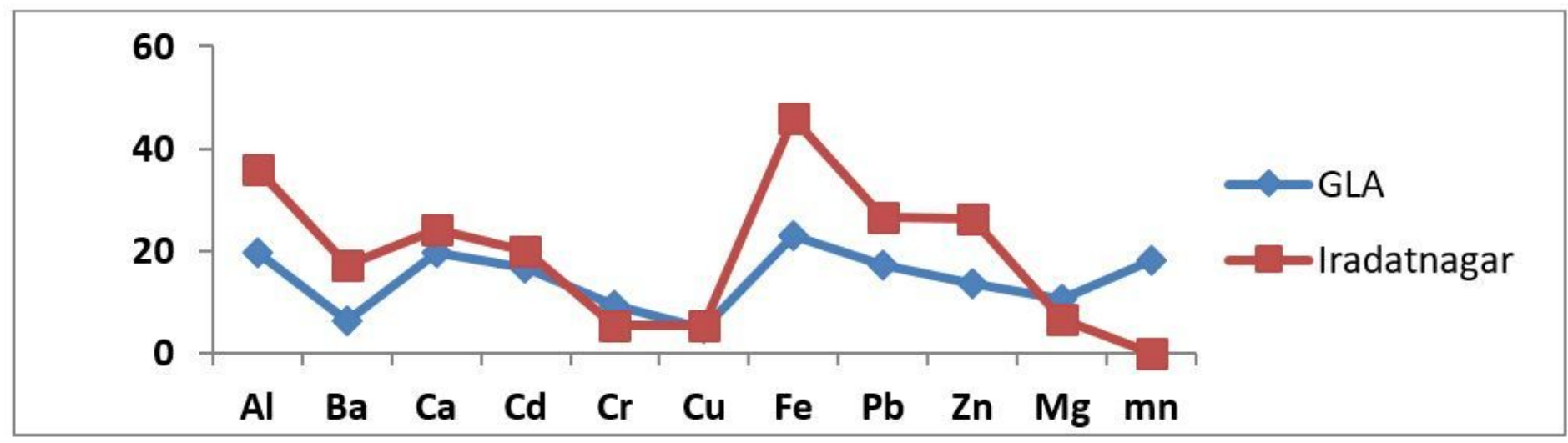

Figure 6

Bioavailability Index of metalsin PM1.0-0.5at different sampling site. (Values in \%) 


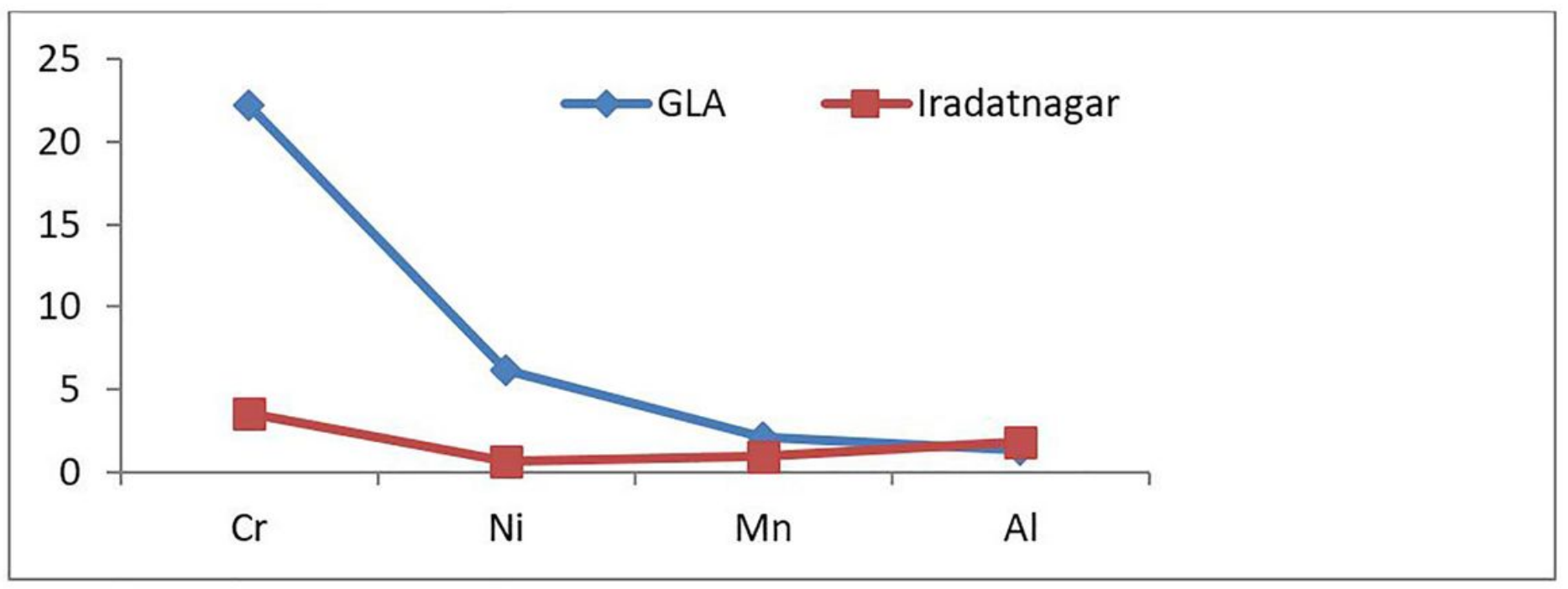

(a)

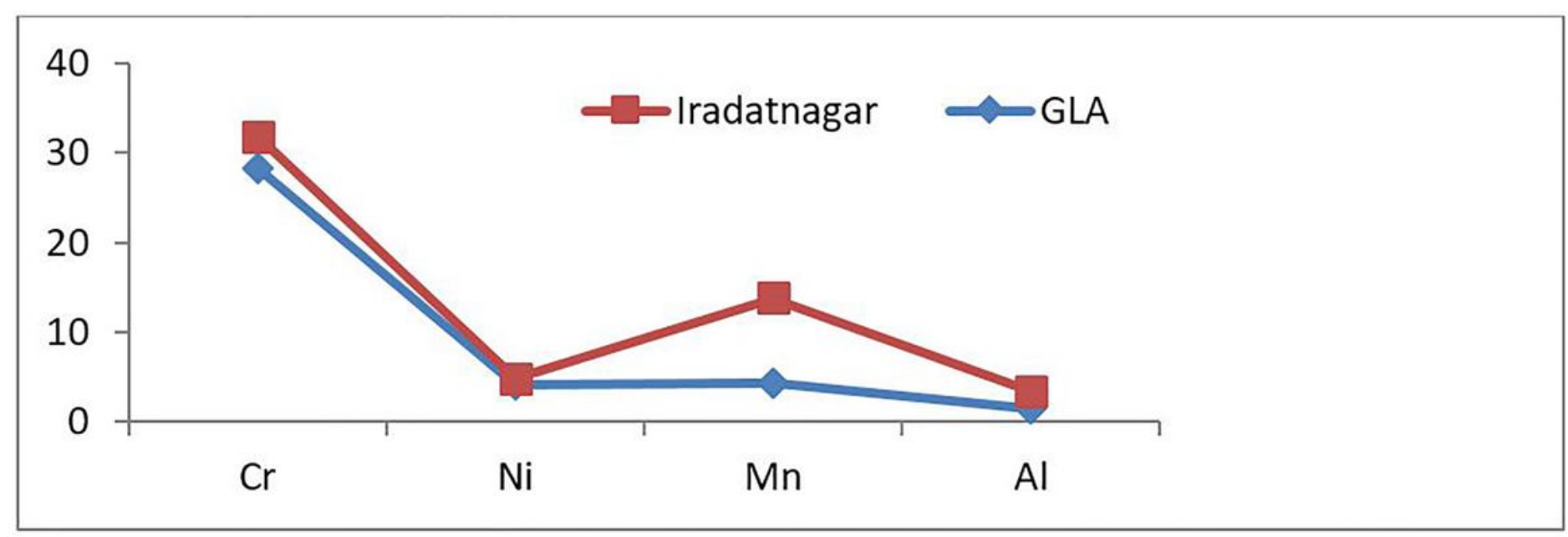

(b)

Figure 7

(a) HQ value For PM2.5-1.0. (b) HQ value For PM1.0-0.5. 


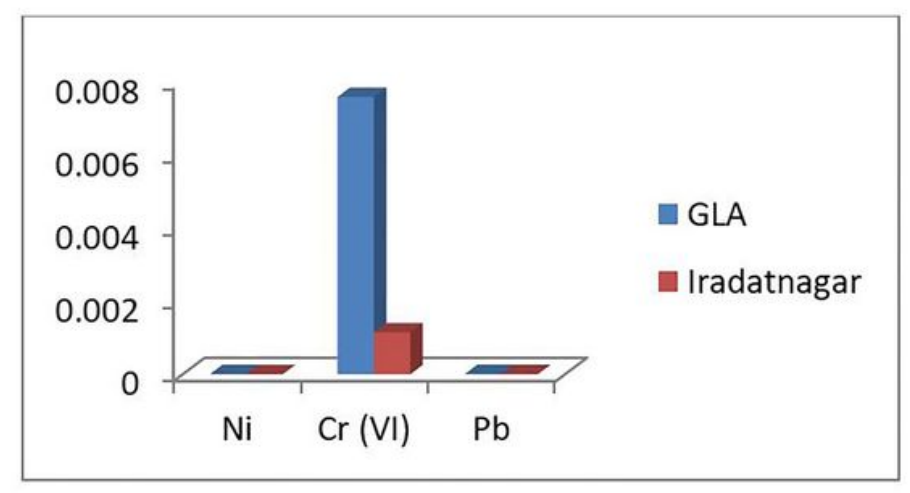

(a)

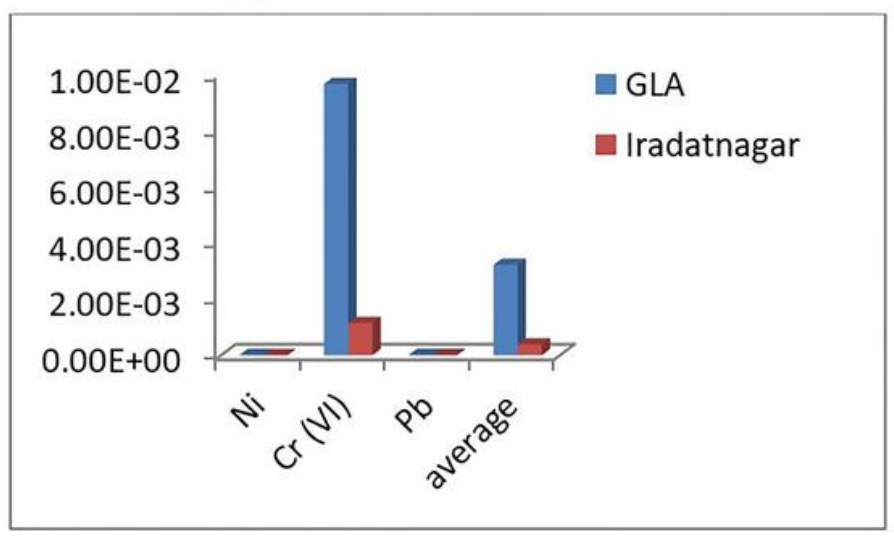

(c)

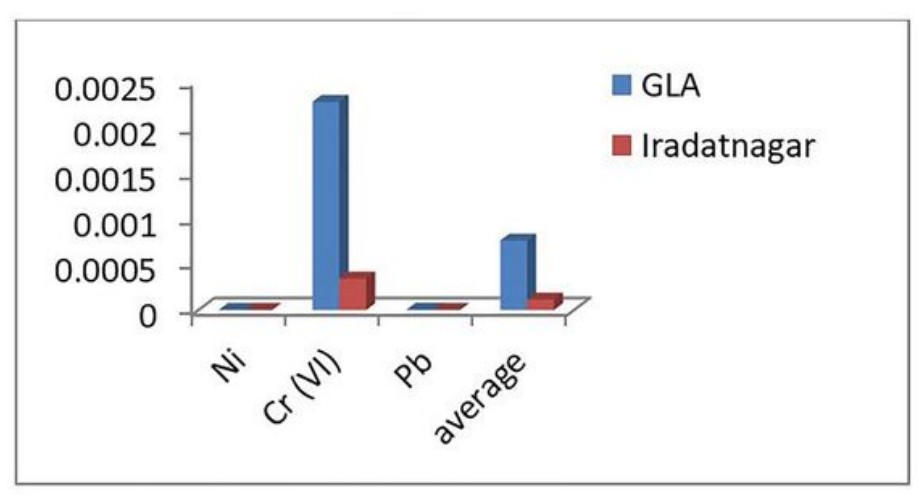

(b)

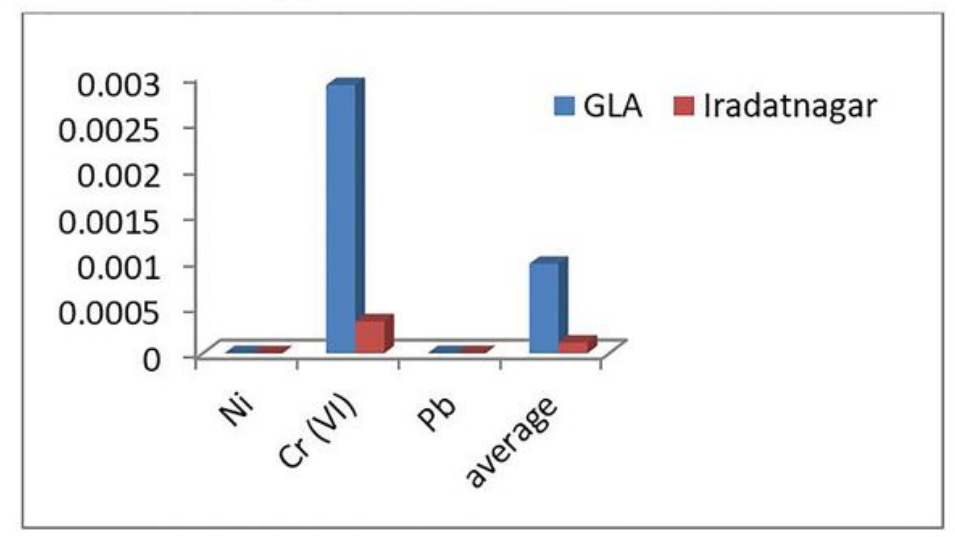

(d)

\section{Figure 8}

(a) ELCR values of PM2.5-1.0 for Adult. (b) ELCR values of PM2.5-1.0 for Child. (c) ELCR values of PM1.00.5 for Adult. (d) ELCR values of PM1.0-0.5 for Child.

\section{Supplementary Files}

This is a list of supplementary files associated with this preprint. Click to download.

- graphicsabstract.jpg 